\title{
Methods to the Principle of Austerity in European Linguistics
}

\author{
Hamdamova Gulshan Hamroevna, Jabbarova Dilafruz Sharofovna, Turakulova Dilafruz \\ Khahhorovna
}

\begin{abstract}
The subject of austerity is deeply studied in European linguistics. A great deal of research has been done on the subject, especially in French, Spanish, Russian and English. We examined the extent of the drop-out event in European languages, mainly in French, Russian, and English. This topic is very elaborate in English. An analysis of a case study of the principle of austerity shows that linguists often overlook the easy recovery of sentence fragments in the analysis of different types of sentences. Therefore, their analysis shows the confusion of words and incomplete sentences. The main theme of the article is to analyze the principle of austerity in European languages with the comparison of Uzbek language.
\end{abstract}

Keywords : Principle, austerity, linguistics, pragmatic analysis, European linguistics, Asian studies, cognitive linguistics..

\section{INTRODUCTION}

$O_{\text {ne of the central issues in morphology is the principle }}$ of austerity that has attracted the attention of Ferdinand de Saussure. He wrote, "It is well known to us how many elements there should be, and we compare the elements in a particular sentence with those elements of the imagination, thus identifying the missing elements.".

\section{LITERATURE REVIEW}

The earliest information on the principle of austerity is found in the works of Greek and Roman scholars of ancient and medieval times - Quintilian, Donat, Harisy, Diamed, Pomponi, Cassiodorus, Isidore, Priscian and others. The subject of austerity is deeply studied in European linguistics. A great deal of research has been done on the subject, especially in French, Spanish, Russian and English. We examined the extent of the drop-out event in European languages, mainly in French, Russian, and English. This topic is very elaborate in English.

In 1765 a scientific article "French rhetoric" was published. It reads as follows: "The principle of austerity arises from

Revised Manuscript Received on October 15, 2019.

* Correspondence Author

Hamdamova Gulshan Hamroevna *, Teachers of Foreign Languages Faculty,Bukhara State University,Uzbekistan

Jabbarova Dilafruz Sharofovna, Teachers of Foreign Languages Faculty,Bukhara State University,Uzbekistan

Turakulova Dilafruz Khahhorovna, Teachers of Foreign Languages Faculty,Bukhara State University,Uzbekistan intense emotion that prevents the speaker from speaking what he or she has to say." Later, French linguists began to pay attention to the grammatical aspects of this phenomenon: "Austerity is the fall of an easy-to-remember phrase."

\section{METHODS}

Consequently, the concept of austerity differs from the concept of "closure ". In case of omission, only words or units are omitted in the context. Its omitted part is understood from the rest, so the principle of saving is different from the concept of "shut down". In case of omission, only words or units are omitted in the context.

He wrote that the phenomenon of austerity is widely understood in the work of S. Adler. S. Adler distinguishes 4 types of the principle of saving in French:

1) pragmatic - the excess of general content in relation to the information provided in the text: Les trois meilleures choses de la vie sont: un cognac avant, une cigarette apris; "The two best things in life are: first cognac and then tobacco."

2) Metallurgical - where the speaker does not feel the drop of the sentence, it does not feel: it falls under the grammatical rules of the language and is paradigmatic.

\section{ANALYSIS}

The language units, the system of grammatical forms, and the system of their individual meaning, occur on the surface: Paul croit aimer Marie (Paul croit küil aime Marie). "Paul believes he loves Maria (Paul believes he loves Maria)" 3) Grammatically - it is possible to say without a person who has a form of this type and the link is: (Il est) inutile dynastic. "It is useless to resist." (It`s) Useless to insist. 4) syntactic - it is possible to repeat the following elements: Paul est party. Je sais (bridal party). Paul's gone. I know (he's gone) M. Greviss shows three types of the principle of saving in French: 1) The principle of false saving (full form never existed): - Parables: Loin des yeux, loin du coeur; Far from sight, far from heart command forms: Venez! Come! 2) The principle of etymological austerity (shortened in time for austerity but not currently felt by the listener). For example: - le 16 janvier le 16 jour du mois de janvier. January 16 . $\leftarrow$ Sixteenth day of January. 
An analysis of a case study of the principle of austerity shows that linguists often overlook the easy recovery of sentence fragments in the analysis of different types of sentences. Therefore, their analysis shows the confusion of words and incomplete sentences. While speaking about the need to distinguish contextual and grammatical detail in the syntactic structure, Layonz uses the terms "adapted" and "incomplete" as synonyms. N.Y. Ivanilova delves into the principle of austerity by separating phrases based on retrieval. Another type of saving principle in the speech, he argues, is that the elements of colloquial speech fall apart; The fall is due to the high frequency of application of these slices and the reflection of the meaning of the word in a different meaning in the speech. In addition, J.R. We have seen how Le Bidois follows the principle of austerity by dividing into two types in French: 1) The principle of partial saving - the slices are dropped to avoid duplication. 2) The principle of total savings is the fall of a whole sentence.

J.G. Testelets conducts research on the drop-out event in the Russian language and lists the phenomenon of austerity in Russian as compared to English. These are 9 in English and 6 in Russian. 1. VP (verb phrase) ellipsis - derivation of verb combination 21: Joan [wrote a novel], and Marvin did [VP write a novel], too. The Valley of the Nile In Nikog takoy vkusnoy vody ne pil. (Paducheva 1974: 178) I love you. [Kira Surikova. «Donna Clara» (2003)]

A.A. Larkina presents modern linguistic views and definitions. It provides definitions of the austerity phenomenon in two different ways: "In the Russian language, linguists have traditionally interpreted this theory as follows:“ The principle of saving is an easy way to speak. In the process of speaking, we try to minimize our speech, but in a way that is clear. "Some linguists describe the grammatical approach: "The principle of austerity is a fallback of a phrase or sentence that can be easily recovered."

. He writes that he has different views in his research. For example, some linguists noted it as "unfinished" and "elliptical."

Concepts of impulsivity and implicitity are very similar to the concept of austerity: 1. Principles of austerity and the power of scientists - who have made observations on voltage It is one or the other in the foregoing in unveiling the essence of this phenomenon the lower parts of the crust. Based on this view, zeugma is part of the complementary discourse that reflects the syntactically different point of view. F. Igragimova also points out the following in the Uzbek language: Bring out a faint smoke from the bad seal, and say a bad word from a bad house; Clever blame himself, foolish friend. This is most common in Uzbek, especially in articles. In both the principle of austerity and the subversion, the components of the sentence are restored by close text. The distinction between these two concepts, depending on the scope or form of action, and the boundary between them, according to F. Ibragimova and N. Makhmudov, do not have a scientific basis. "Zeugma" is a term for literary criticism, which is based on the principle of economy.

\section{DISCUSSION}

In the Uzbek language F. Ibragimova, N.M. Makhmudova in conducted research work on this topic. In her dissertation, F. Ibragimova focuses on the Uzbek language. Summarizing his observations and observations on the principle of saving in general linguistics, he writes: "This process is a syntactic, linguistic, and lingvopoetic phenomenon that results from the principle of austerity at the syntactic level of the language. Fiction can be defined as the deliberate omission of parts of speech during speech by a speaker or writer for a certain methodological and linguistic purpose. "

"Many linguists have noted that the principle of austerity is a common and fundamental factor in language development and language evolution. Much work has been done in Russian linguistics to find solutions to the problems related to austerity and retention. While Ms. Kubryakova argues that the principle of language saving is one of the most powerful internal principles in all languages of the world, A. Budagov believes that the principle of language saving does not relate to language development. As a result of the morphological occurrence of the principle of austerity, there is a drop event. N.M. As Mahmudov specifically states, "Language-saving phenomena play an important role in stylistics and syntax." In other words, the principle of austerity does not occur at any level of the language. The general characteristic of all morphological austerity structures is that the absence of certain elements of the sentence; they have dropped. Consequently, the second part of this sentence (1) in English is shortened by the principle of austerity, as Sevaraloves green tea is omitted. So the original expression of this phrase was: "Akmal loves green tea, and Sevara also loves green tea." Nevertheless, the meaning of the sentence is never compromised. As we shall see in the following example (1), this statement is a clear example of the principle of austerity, read the newspaper in its entirety. In the Uzbek way of subtraction (2), only the verb can be omitted; In the case of (2), what can be cooked is a wonderful kebab obtained from Thanksgiving. As we can see by the Russian method of indirect omission (3), not only the verb (spoke), but the horse as well (about problem)

The principle of linguistic austerity is considered morphologically, but it also examines how this practice should be viewed, demonstrated, and calculated. So, by knowing, we try to answer these questions: How do these words build? What kind of morphological structure can be found on the elastic levels? that is, whether or not the omitted elements are created regardless of the sentence structure or not? And under what conditions can downloads and links be downloaded? As for the division of the expression: How is the structure of these sentences defined? How are they Grammatically analyzed? Are the missing components formed artificially? If this is the case, how can you plan their deduction, and how will they be calculated?

Consequently, the two main issues are discussed in this dissertation: the morphological retrieval of the concept of language saving and the existence of various limitations on adaptive devices. These considerations are based on the analysis of scientific studies by the following linguists: 
The Chomsky, Lasnik, Fiengo, and Mey morphological austerity is believed to be a repetition process that occurs under repetition. However, some examples can be argued against the idea of generalization. It is also shown that the method of deduction should be different from the notion of morphological savings (for example, Chao, Feodor, Berwick and Weinberg).

The context of the dialogues, that is, the words of the speakers, is very important plays a role. On this basis, sections that are not considered main by the speaker are dropped. "Contextual savings in terms of actual fragmentation of the discourse serve to emphasize the theme narrative and to emphasize it". According to Ibragimova, "In Uzbek, in some cases contextual austerity may also be attributed to the omission of certain parts of phraseological expressions. For example: - Don't forget the ginger, too, Shamsiddin Khan! "He will not come out," Shamsiddin says with his hands on his chest. (E.Azam, "Angel"). In the first replica, the phrase "forget" is used, and in the second replica, the most memorable is the contextual saving. The expression for the phrase does not appear in the form of an elliptical sentence and is repeated twice. It is also possible to make observations regarding the use of specific horses (anthroponomy) for a particular purpose. Because some of the names used in the fiction work reveal the writer's artistic and aesthetic intentions will help. The phenomenon associated with the use of well-known horses in these functions is summarized in some literature under the name of antonomy. In the Uzbek literature, the names that give rise to the character of the character are often found in the comic books of writers Abdullah Kadiri, Abdullah Qahhor, Said Ahmad and others. For example, the Makhzawa kori (A. Kadiri); Jonfighan, Narin Cholpiq (A. Kahhor); In the names of such heroes as Goyipnazar Pinhonov, Oldi Sottiyev, Commercialkhan (S. Ahmad), the writer's irony is apparent. Our talented writers strive to create unique images by linking the hero's life, destiny and spirit with his name. It is certainly a linguistic skill of the writer, and one can penetrate into the poetic world of the writer by examining such cases.

Based on the foregoing, the following conclusions were reached: 1 . The peculiarity of the analysis of elements of the cross section function based on the linguistic methods we approach, comparatively typological, with a focus on the problem of skulls and partly on the linguists' views. 2. In traditional grammar, we prefer a new approach to classification of the cross section, given that there is no consensus on classification of the cross section in either language or it is a controversial issue. 3. When syntactically substituting syntactic units that are in place of the main parts of the speech, they are categorized into categorical symbols such as procedural, qualitative and subversive. Using this categorical differential syntactic-semantic character, each of them is further divided into several non-categorical types. In particular, based on procedural criteria from the categorical symbols, syntaxes such as asset-negative, asset-modal, asset-modal negatives were identified. An active syntax associated with a core predicate link is associated with agent (action), agent-negative, elective (choice) syntax, subject to subordinate communication, object-locator, object-agent, temporal (time), object-active , social (co-occurring),

elective-elective, static (comparative), quantifiable, object-static (assumed) and associated syntax. It has been established that a syntax that identifies on the basis of subconscious syntax can be linked to syntax, which is quantitative, object-quantum, comparative, positional, commutative, based on subordinate communication.

\section{CONCLUSION}

A Thus, when referring to cognitive retardation, the fact that the concept of morphological savings is based on different examples can be used as a basis for minimalist theory of analysis (as in (4)). (6) and (7 indirect and indirect methods, below) The following examples show that this is a clear indication: - (6) Alisher phoned his friend, and Ravshan did too. - (7) a. Bekzod saw his friend and his brother Farhad. (indirect) b. Bekzod uvidel svoego druga, a Farhad uvidel brata. (directly) Therefore, the urgency of learning the principle of saving in speech is of great importance in English as retrieval is one of the most popular and controversial issues of modern morphology. The issue of austerity has always been a fundamental concern in linguistics: the relationship between language and thought, logic and grammar, form and meaning, among them. As Lasnik fully acknowledges, Dropping is one of the oldest linguistic problems. For many centuries, various language researchers have proposed a classification of suggestions by explaining this phenomenon and trying to identify its basic features. Foreign and local scientists have long been trying to classify this problem. The authors of some of the works have made a significant contribution to the study of this issue by attempting to explain the method of retrieval in English. However, scientists have not yet reached a consensus on many issues of the principle of austerity.

\section{REFERENCES}

1. Ángel J. GALLEGO. CLT - Universitat Autònoma de Barcelona. 143c.

2. Merchant J. The syntax of silence: sluicing, islands, and the theory of ellipsis. - Oxford,NY: OUP, 2001. 243p

3. Richards M. Object Shift and Scrambling in North and West Germanic: A Case Study in Symmetrical Syntax. PhD dissertation. - University of Cambridge, 2004. - B. 153p.

4. Richards. M. On Feature Inheritance: An Argument from the Phase Impenetrability Condition, Linguistic Inquiry. - 2007. 108p

5. Lasnik H. Pseudogapping puzzles in S. Lappin and E. Benmamoun (eds.), Fragments:Studies in Ellipsis and Gapping. - New York: OUP, 1999 $187 \mathrm{p}$

6. Иванилова Н. Е. Структурно-семантические особенности эллиптических предложений во французском и английском языках (на материале франкоязычных и англоязычных художественных произведений начала XX века): Автореф. дис. ... канд. филол. наук. - Нальчик, 2008. 156c.

7. Le Bidois R. A propos de l'implicitation du verbe dans les propositions comparatives // Le frangais modern - Avril 1956. / Le Bidois R. Syntaxe $\mathrm{du}$ frangais moderne. Ses fondements historiques et psychologiques Paris: Edition Ricard, 1971. 211c.

8. Marouzeau J. Lexique de la terminologie linguistique. - Paris: Geuther, 1933.

9. Tancredi, C. Deletion, Deaccenting, and Presuposition. Doctoral Dissertation. MIT, Cambridge, Mass. - 1993. 29p.

10. Weinberg, A. "A Minimalist Theory of Human Sentence Processing.” In Working Minimalism, ed. Samuel Epstein and Norbert Horstein. Cambridge, Mass.: MIT Press. - 1999. 176p.

11. Williams, Edwin. Discourse and Logical Form. Linguistic Inquiry 8. 1977 